\title{
Seossuhteen ja kylvöajankohdan vaikutus ohran ja kevätrypsin kilpailuun
}

\author{
LEILA-RiITta ERviö \\ Helsingin yliopiston kasvinviljelytieteen laitos, Viikki, 00710 Helsinki
}

\section{The effect of mixture composition and time of sowing on the competition between barley and spring turnip rape}

\author{
LeILA-RittTa ERviö \\ Department of Plant Husbandry, University of Helsinki, 00710 Helsinki.
}

\begin{abstract}
The effect of mixture composition and time of sowing of spring turnip rape on the competition between barley and spring turnip rape was investigated in two pot trials in a greenhouse. The basis for the study was competition between weeds and a cereal crop. Since no seed of a weed of the genus Brassica was available, spring turnip rape cv. Fenno was chosen as replacement, a species developed from weed to cultivated plant as late as the $1940 \mathrm{~s}$.

Growth density in both experiments corresponded to 2000 plants per $\mathrm{m}^{2}$. In Experiment I the proportions of barley and turnip rape were $100,75-25,50-50,25-75$ and $100 \%$. In Experiment II equal numbers of plants of both species were grown in mixed stand with five different sowing dates for the turnip rape.

Results showed that barley as the stronger competitor lowered the plant weight and dry-matter yield of the turnip rape the more, the later its sowing date in relation to the barley. The turnip rape, on the other hand, had no detrimental effect on the barley.

Crowding coefficients calculated for the two species also showed that barley was a more aggressive competitor than turnip rape in both experiments. Late sowing of the turnip rape in relation to barley caused its crowding coefficient to fall the more, the later the date of sowing.
\end{abstract}

Keskenään kilpailevien kasvien vaikutusta toisiinsa on pyritty mittaamaan monin tavoin. Useissa tutkimuksissa on osapuolien välinen vaikutus ilmaistu niiden toisilleen aiheuttamina sadon alennuksina tai ulkonäön muutoksina. Esimerkiksi BoRnKAммin (1960) mukaan kasvin yksilönpaino jää sitä pienemmäksi, mitä voimakkaamman kilpailijan kanssa se kasvaa. Satotulosten tai kasvustossa kasvaneitten yksilöitten lukumäärän perusteella on myös laadittu kaavoja kasvien kilpailukyvyn laskemiseksi matemaattisesti (mm. de WiтT 1960 , LAMPETER 1959/60).

Helsingin yliopiston kasvinviljelytieteen laitoksella suoritettiin vuosina 1965-71 sarja tutkimuksia, joissa pyrittiin selvittämään rikkakasvien kil- 
pailukykyä erilaisissa kasvuoloissa (ERvı̈ 1971, 1972 a ja b). Kilpailukyvyn muuttumisen katsottiin tällöin ilmenevän satotuloksien, yksilönpainojen ja ulkonäön muutoksina. Tutkimuksia jatkettiin vuonna 1972, jolloin verrattiin ohran ja Fenno-kevätrypsin kilpailukykyä sekakasvustossa. Kasvien kilpailukykyä ilmentävien satotulosten ja yksilönpainon muutosten lisäksi kuvattiin tällöin lajien aggressiivisuutta valtauskertoimella (LAMPETER 1959/60).

\section{Tutkimusaineisto ja -menetelmät}

Tutkimus käsitti kaksi astiakoetta, jotka suoritettiin kasvihuoneessa keskimääräisen lämpötilan kokeen aikana ollessa $19.5 \mathrm{C}^{\circ}$. Kasvualustana käytettiin lannoitetun kasvuturpeen (N 0.1, P 0.1, K 0.2, Ca $1.6 \%$ kuivapainosta, lisäksi hivenaineet) ja hiekan seosta suhteessa $3: 1$ ja koeastioina viiden litran vetoisia muovikannuja, joissa kasvupinta-ala oli $284 \mathrm{~cm}^{2}$. Kun lähtökohtana tutkimukselle oli rikkakasvien ja viljan välinen kilpailu, mutta käytettävissä ei ollut Brassica-suvun rikkakasvien siementä, valittiin sitä edustamaan Fenno-kevätrypsi. Tämä lajike on nimittäin kehitetty Maatalouden tutkimuskeskuksen kasvinviljelylaitoksella rikkakasvista viljelykasviksi vasta 1940luvulla (VALLE 1951). Toisena osapuolena sekakasvustossa oli kaksitahoinen Arvo-ohra.

Koe I. Astioihin kylvettiin kumpaakin kasvilajia neljänä kerranteena seuraaviksi kasvustoiksi, joiden tiheys vastasi $2000 \mathrm{kpl} / \mathrm{m}^{2}$;

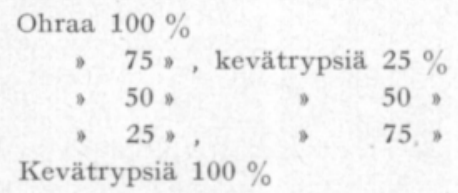

Kasvit korjattiin neljällä kehitysasteella: ohran pensomisen alkaessa (rypsi 3-5-lehtiasteella), ohran pensoessa (rypsi kukki), ohran ollessa tähkällä (rypsin kukinta lopullaan) ja ohran ollessa tuleentunut (rypsi tuleentunut).

Koe II. Astioihin kylvettiin $1000 \mathrm{kpl} / \mathrm{m}^{2}$ vastaava määrä Arvo-ohraa ja saman verran Fenno-kevätrypsiä seuraavina ajankohtina:

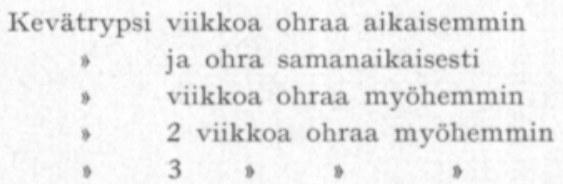

Valtauskertoimen laskemista varten kylvettiin kunakin kylvökertana myös lajin puhdas kasvusto, jonka tiheys vastasi $2000 \mathrm{kpl} / \mathrm{m}^{2}$. Kerranteita oli kolme.

Yhtäaikaa kylvetyt ohra ja rypsi taimettuivat myös samanaikaisesti. Eri aikaan kylvettyjen kasvien kehitysasteet toisiinsa verrattuina ilmenevät taulukosta 1 . 
Taulukko 1. Kylvöajankohdan vaikutus kevätrypsin kehittymiseen ohraan verrattuna.

Kevätrypsin kylvöajankohdat: $1=$ viikkoa ohraa aikaisemmin, $2=$ samanaikaisesti kuin ohra, $3=$ viikkoa ohraa myöhemmin, $4=2$ viikkoa ohraa myöhemmin, $5=3$ viikkoa ohraa myöhemmin.

Table 1. Effect of the sowing date on the development of spring turnip rape compared with barley. Sowing dates of turnip rape: $1=1$ week before barley, $2=$ same date as barley, $3=1$ week after barley, $4=2$ weeks after barley, $5=3$ weeks after barley.

\begin{tabular}{|c|c|c|c|c|c|}
\hline \multirow{2}{*}{ Ohra - Barley } & \multicolumn{5}{|c|}{ Kevätrypsi - Spring turnip rape } \\
\hline & 1 & 2 & 3 & 4 & 5 \\
\hline $\begin{array}{l}\text { orastunut } \\
\text { emerged }\end{array}$ & $\begin{array}{l}\text { 2-lehtiaste } \\
2 \text { leaf stage }\end{array}$ & $\begin{array}{l}\text { taimettunut } \\
\text { emerged }\end{array}$ & - & - & - \\
\hline $\begin{array}{l}\text { 2-lehtiaste } \\
2 \text { leaf stage }\end{array}$ & $\begin{array}{l}\text { 3-lehtiaste } \\
3 \text { leaf stage }\end{array}$ & $\begin{array}{l}\text { 1-lehtiaste } \\
1 \text { leaf stage }\end{array}$ & - & - & - \\
\hline $\begin{array}{l}\text { 3-lehtiaste } \\
3 \text { leaf stage }\end{array}$ & $\begin{array}{l}\text { 3-4-lehtiaste } \\
3-4 \text { leaf stage }\end{array}$ & $\begin{array}{l}\text { 1-2-lehtiaste } \\
1-2 \text { leaf stage }\end{array}$ & $\begin{array}{l}\text { taimettunut } \\
\text { emerged }\end{array}$ & - & - \\
\hline $\begin{array}{l}3-4 \text {-lehtiaste } \\
3-4 \text { leaf stage }\end{array}$ & $\begin{array}{l}4-5 \text {-lehtiaste } \\
4-5 \text { leaf stage }\end{array}$ & $\begin{array}{l}3-4 \text {-lehtiaste } \\
3-4 \text { leaf stage }\end{array}$ & $\begin{array}{l}\text { sirkkalehtiaste } \\
\text { cotyledons }\end{array}$ & $\begin{array}{l}\text { taimettunut } \\
\text { emerged }\end{array}$ & - \\
\hline $\begin{array}{l}1 \text { sivuverso } \\
1 \text { tiller }\end{array}$ & $\begin{array}{l}\text { nuppuaste } \\
\text { flower-bud stage }\end{array}$ & $\begin{array}{l}3-5 \text {-lehtiaste } \\
3-5 \text { leaf stage }\end{array}$ & $\begin{array}{l}2-3 \text {-lehtiaste } \\
2-3 \text { leaf stage }\end{array}$ & $\begin{array}{l}1-2 \text {-lehtiaste } \\
1-2 \text { leaf stage }\end{array}$ & $\begin{array}{l}\text { taimettunut } \\
\text { emerged }\end{array}$ \\
\hline $\begin{array}{l}\text { pensomisaste } \\
\text { tillering }\end{array}$ & $\begin{array}{l}\text { kukkimisaste } \\
\text { flowering }\end{array}$ & $\begin{array}{l}\text { nuppuaste } \\
\text { flower-bud stage }\end{array}$ & $\begin{array}{l}3-5 \text {-lehtiaste } \\
3-5 \text { leaf stage }\end{array}$ & $\begin{array}{l}2-4 \text {-lehtiaste } \\
2-4 \text { leaf stage }\end{array}$ & $\begin{array}{l}\text { 1-2-lehtiaste } \\
1-2 \text { leaf stage }\end{array}$ \\
\hline $\begin{array}{l}\text { pensomisaste } \\
\text { (viikkoa myöhemmin) } \\
\text { tillering (a week later) }\end{array}$ & $\begin{array}{l}\text { /lituja } \\
\text { /siliques }\end{array}$ & $\begin{array}{l}\text { /kukkia } \\
\text { /flowers }\end{array}$ & $\begin{array}{l}\text { /nuppuja } \\
\text { /flower buds }\end{array}$ & $\begin{array}{l}3-5 \text {-lehtiaste } \\
3-5 \text { leaf stage }\end{array}$ & $\begin{array}{l}\text { 2-lehtiaste } \\
2 \text { leaf stage }\end{array}$ \\
\hline $\begin{array}{l}\text { vihneet näkyvissä } \\
\text { awns visible }\end{array}$ & $\begin{array}{l}\text { siemeniä } \\
\text { seeds }\end{array}$ & $\begin{array}{l}\text { kukkia/lituja } \\
\text { flowers/siliques }\end{array}$ & $\begin{array}{l}\text { nuppuja/kukkia } \\
\text { flower buds/ } \\
\text { flowers }\end{array}$ & $\begin{array}{l}\text { nuppuaste } \\
\text { flower-dud stage }\end{array}$ & $\begin{array}{l}2-3 \text {-lehtiaste } \\
2-3 \text { leaf stage }\end{array}$ \\
\hline jyvät kehittymässä & siemeniä & $\begin{array}{l}\text { kukinta päätty- } \\
\text { nyt/lituja }\end{array}$ & kukkia/lituja & kukkimisaste & kukkimisaste \\
\hline grains developing & seeds & $\begin{array}{l}\text { flowering ended/ } \\
\text { siliques }\end{array}$ & flowers/siliques & flowering & flowering \\
\hline $\begin{array}{l}\text { tuleentumisaste } \\
\text { maturity }\end{array}$ & $\begin{array}{l}\text { tuleentunut } \\
\text { maturity }\end{array}$ & $\begin{array}{l}\text { siemeniä } \\
\text { seeds }\end{array}$ & $\begin{array}{l}\text { siemeniä } \\
\text { seeds }\end{array}$ & $\begin{array}{l}\text { kukkia/siemeniä } \\
\text { flowers/seeds }\end{array}$ & $\begin{array}{l}\text { kukkimisaste } \\
\text { flowering }\end{array}$ \\
\hline
\end{tabular}

Molempia kokeita korjattaessa punnittiin kasvien kuiva-ainesato, määritettiin juuri-, varsi-, lehti- ja siemensadon osuudet seka laskettiin kasvien yksilökohtainen paino. Valtauskerroin laskettiin LAMPETERin (1959/60) kehittämästä kaavasta, joka perustuu kasvin tuottamaan satoon seka- ja puhtaassa kasvustossa.

\section{Tulokset}

Koe $I$, seossuhteen vaikutus. Kilpailu sekakasvustossa vaikutti kasvilajien yksilönpainoon eri tavoin. Ohran yksilönpaino oli pienin puhtaassa kasvustossa, mutta seoksessa sitä suurempi, mitä vähäisempi sen osuus kasvustossa oli, kun taas rypsin yksilönpaino jäi sekakasvustossa pienemmäksi kuin puhtaassa kasvustossa seossuhteen siihen vaikuttamatta (kuva 1). 


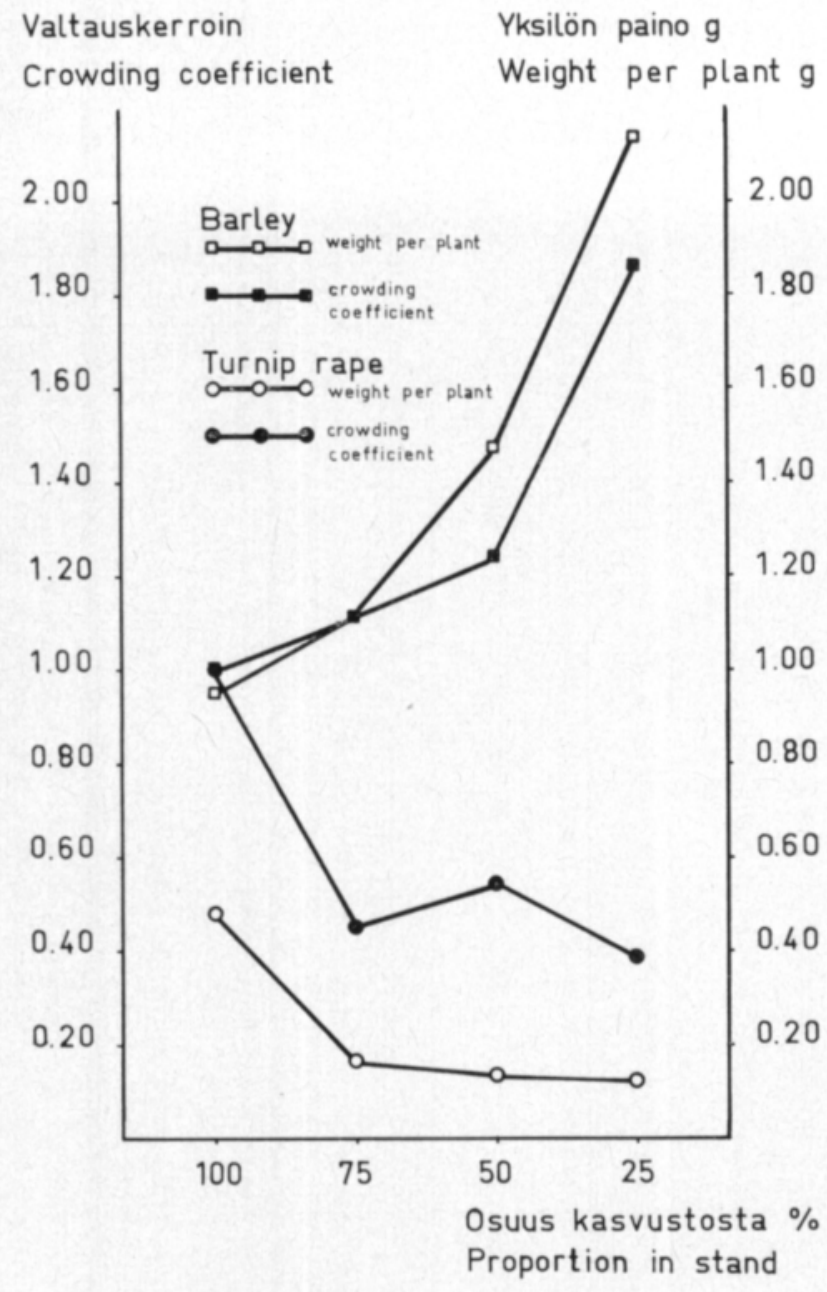

Kuva 1. Seossuhteen vaikutus ohran ja rypsin yksilönpainoon ja valtauskertoimeen. Fig. 1. Effect of mixture composition on the weight per plant and crowding coefficients of barley and spring turnip rape.

Kummankin kasvilajin kuiva-ainesato oli suurempi puhtaassa kuin sekakasvustossa (taulukko 2), mutta rypsin sato pieneni jyrkemmin ja kokonaisuudessaan suhteellisesti enemmän kuin ohran, kun lajin osuus sekakasvustossa väheni.

Seossuhde ei vaikuttanut tutkittujen kasvilajien juuri-, lehti- ja siemensadon osuuksiin.

Myös molempien kasvilajien valtauskertoimen kehitys osoittaa ohran hyötyneen kilpailusta rypsin kanssa. Ohran valtauskerroin nimittäin kohosi puhtaaseen kasvustoon verrattuna sitä enemmän, mitä pienempi lajin osuus sekakasvustossa oli (kuva 1). Sen sijaan rypsin valtauskerroin jäi kaikissa sekakasvustoissa huomattavasti pienemmäksi (F 11.00***) kuin puhtaassa kasvustossa. Ohran tehokasta kilpailukykyä kuvastaa myös sen valtauskertoimen kohoaminen kasvuajan kuluessa ensimmäisestä korjuukerrasta lähtien, kun taas sitä heikomman kilpailijan, rypsin, valtauskerroin vastaavasti pieneni (kuva 2). 
Taulukko 2. Seossuhteen vaikutus ohran ja rypsin satoon tuleentumisvaiheessa.

Table 2. Effect of mixture composition on the yields of barley and spring turnip rape at the time of maturity.

\begin{tabular}{|c|c|c|}
\hline \multirow[t]{2}{*}{$\begin{array}{c}\text { Osuus kasvustosta \% } \\
\text { Percentage of stand }\end{array}$} & \multicolumn{2}{|c|}{$\begin{array}{c}\text { Sato, } \mathrm{sl}^{1} \text { ) } \\
\text { Relative yield }\end{array}$} \\
\hline & $\begin{array}{l}\text { Ohra } \\
\text { Barley }\end{array}$ & $\begin{array}{c}\text { Kevätrypsi } \\
\text { Spring turnip rape }\end{array}$ \\
\hline 100 ................................ & $100^{\mathrm{e}}$ & $100^{\mathrm{b}}$ \\
\hline $75 \ldots \ldots \ldots \ldots \ldots \ldots$ & $86^{\text {be }}$ & $22^{a}$ \\
\hline $50 \ldots \ldots \ldots \ldots \ldots$ & $78^{\mathrm{b}}$ & $10^{\mathrm{a}}$ \\
\hline 25 ........................... & $55^{\mathrm{a}}$ & $5^{\mathrm{a}}$ \\
\hline
\end{tabular}

1) Samalla yläindeksillä merkityt luvut samassa sarakkeessa eivät poikkea toisistaan merkitsevästi.

Values in the same column followed by the same letter do not differ significantly.

Kuva 2. Ohran ja rypsin valtauskertoimen kehitys kasvukauden aikana. Korjuuajankohdat: $1=$ ohran pensomisen alku, 2 = ohran pensomisaste, $3=$ ohra tähkällä, $4=$ ohra tuleentunut.

Fig. 2. Development of crowding coefficients of barley and spring turnip rape during the growing season. Harvesting dates: $1=$ barley beginning tillering, 2 = barley tillering, $3=$ barley heading, $4=$ barley maturing.

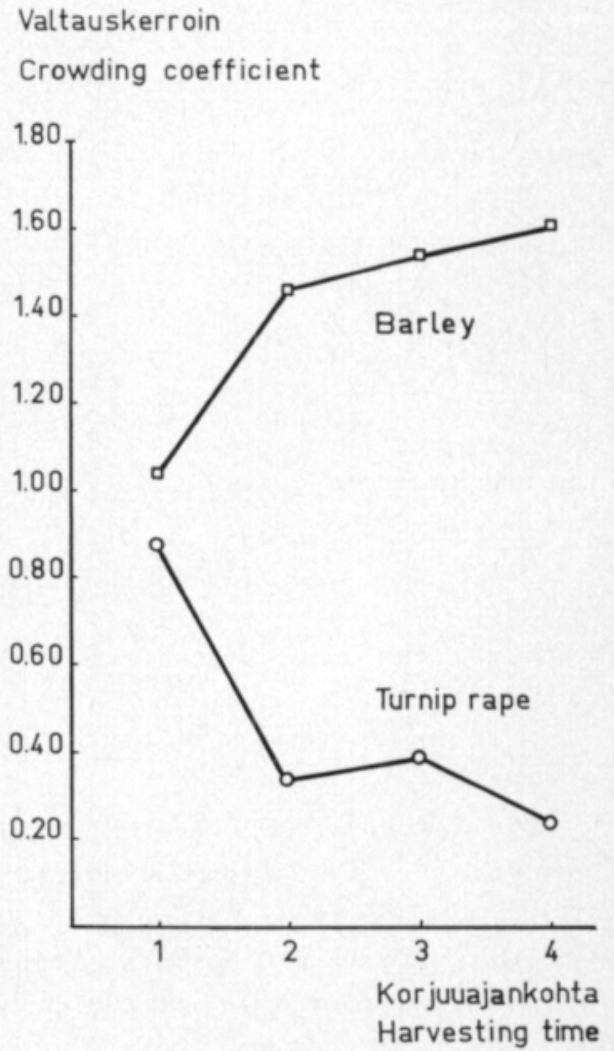

Koe II, kylvöajankohdan vaikutus. Rypsin kilpailu ohran kanssa ei vaikuttanut ohran yksilönpainoon. Sen sijaan rypsin yksilönpaino oli puhtaassa kasvustossa keskimäärin $1.75 \mathrm{~g}$, mutta sekakasvustossa vain $0.29 \mathrm{~g}$. Myös kylvöajankohta vaikutti sekakasvustossa rypsiyksilöitten painoon. Ennen ohraa tai samanaikaisesti sen kanssa kylvetyt ja myös taimettuneet rypsiyksilöt olivat painavampia kuin sitä myöhemmin pinnalle nousseet, kuten oheisesta asetelmasta ilmenee: 


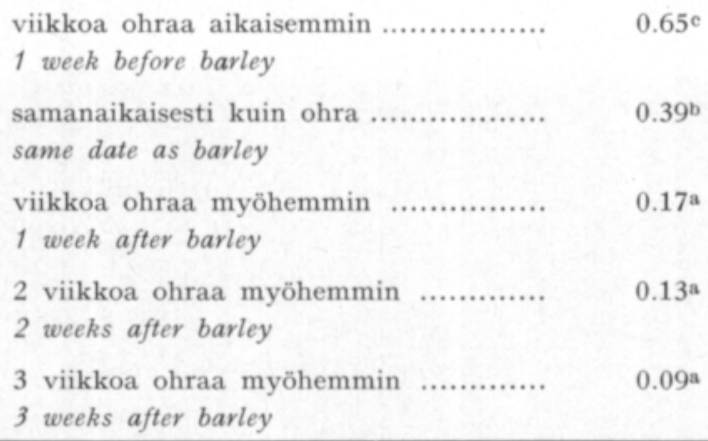

1) Samalla yläindeksillä merkityt luvut eivät poikkea toisistaan merkitsevästi. Values followed by the same letter do not differ significantly.

Toisin kuin edellisessä kokeessa ohran sadossa puhtaan ja sekakasvuston välillä ei ilmennyt merkitseviä eroja. Rypsin sato sitä vastoin jäi erittäin paljon pienemmäksi seka- kuin puhtaassa kasvustossa:

\begin{tabular}{|c|c|c|}
\hline & $\begin{array}{l}\text { Ohra } \mathrm{sl}^{\mathbf{1}} \text { ) } \\
\left.\text { Barley, }{ }^{1}\right) \\
\text { relative yeld }\end{array}$ & $\begin{array}{l}\text { Rypsi } \text { sl. }^{1} \text { ) } \\
\left.\text { Spring turnip rape, }{ }^{1}\right) \\
\text { relative yield }\end{array}$ \\
\hline Puhdas kasvusto - Pure stand ................... & $100^{\mathrm{a}}$ & $100^{\mathrm{b}}$ \\
\hline Sekakasvusto - Mixed stand ..................... & $91 \mathrm{a}$ & $16^{\mathrm{a}}$ \\
\hline
\end{tabular}

1) Samalla yläindeksillä merkityt luvut samassa sarakkeessa eivät poikkea toisistaan merkitsevästi.

Values in the same colum followed by the same letter do not differ significantly.

Rypsin kylvöajankohta muutti sen ja ohran suhteellisia osuuksia sadossa (taulukko 3). Ohran osuus sekakasvuston sadosta oli pienimmillään ja rypsin suurimmillaan, kun se kylvettiin ohraa aikaisemmin. Tästä rypsin osuus väheni noin puoleen ohran osuuden vastaavasti lisääntyessä, kun rypsi kylvettiin yhtäaikaa ohran kanssa, ja noin neljännekseen tai sitä pienempään kylvön tapahtuessa myöhemmin kuin ohran.

Rypsin kylvöajankohta ei vaikuttanut sen sadon määrään puhtaassa kasvustossa eikä ohran satoon kummassakaan kasvustossa. Sen sijaan rypsin sato sekakasvustossa oli suurin ennen ohraa kylvettäessä ja väheni kylvön siirtyessä ohraa myöhäisemmäksi (kuva 3). Ohran kilpailu alensi rypsin satoa aikaisempaan kylvöajankohtaan verrattuna jo silloin, kun molemmat kasvilajit kylvettiin samanaikaisesti. Erittäin voimakkaana ilmeni kilpailun satoa alentava vaikutus rypsissä, kun tämä kylvettiin ohraa myöhemmin. Myöhäisten kylvöksien keskinäiset satoerot eivät olleet tilastollisesti merkitsevät. 
Taulukko 3. Kevätrypsin kylvöajankohdan vaikutus sen ja ohran osuuteen sekakasvuston sadosta.

Table 3. Effect of the sowing date of spring turnip rape on the relative proportions of turnip rape and barley in the yield of mixed stand.

\begin{tabular}{|c|c|c|}
\hline \multirow[t]{3}{*}{$\begin{array}{l}\text { Kevätrypsin kylvōajankohta } \\
\text { Sowing date of spiring turnip rape }\end{array}$} & \multicolumn{2}{|c|}{$\begin{array}{l}\text { Osuus sadosta } \%^{1} \text { ) } \\
\text { Percentage of } \text { yield }^{1} \text { ) }\end{array}$} \\
\hline & Ohra & Kevätrypsi \\
\hline & Barley & Spring turnip rape \\
\hline $\begin{array}{l}\text { Viikkoa ohraa aikaisemmin } \ldots \ldots \ldots \ldots \ldots \ldots \ldots \ldots \ldots \ldots \ldots \ldots \ldots \ldots \ldots \\
1 \text { week before barley }\end{array}$ & $75.7^{a}$ & $24.3^{\mathrm{e}}$ \\
\hline 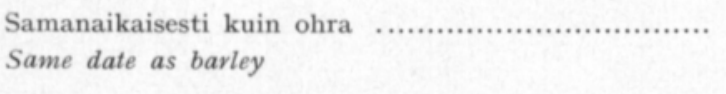 & $87.8^{b}$ & $12.2^{b}$ \\
\hline $\begin{array}{l}\text { Viikkoa ohraa myöhemmin } \ldots \ldots \ldots \ldots \ldots \ldots \ldots \ldots \ldots \ldots \ldots \ldots \ldots \ldots \ldots \ldots \\
t \text { week after barley }\end{array}$ & $93.9^{\mathrm{c}}$ & $6.1^{\mathrm{a}}$ \\
\hline $\begin{array}{l}2 \text { viikkoa ohraa myöhemmin } \ldots \ldots \ldots \ldots \ldots \ldots \ldots \ldots \ldots \ldots \ldots \ldots \ldots \ldots \ldots \ldots \ldots \\
2 \text { weeks after barley }\end{array}$ & $96.2^{e}$ & $3.8^{\mathrm{a}}$ \\
\hline 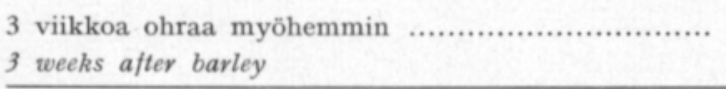 & $97.1^{\mathrm{e}}$ & $2.9^{\mathrm{a}}$ \\
\hline
\end{tabular}

1) Kts. selitystä taulukossa 2 .

See explanation in table 2.

Kuva 3. Kylvöajan vaikutus rypsin satoon sekakasvustossa. Rypsin kylvöajankohdat: 1 = viikkoa ohraa aikaisemmin, 2 = samanaikaisesti kuin ohra, $3=$ viikkoa ohraa myöhemmin, $4=2$ viikkoa ohraa myöhemmin, $5=3$ viikkoa ohraa myöhemmin.

Fig. 3. Effect of sowing date on the yield of spring turnip rape in mixed stand. Sowing dates of turnip rape: $1=1$ week before barley, 2 = same date as barley, $3=1$ week before barley, $4=2$ weeks before barley, $5=3$ weeks before barley.

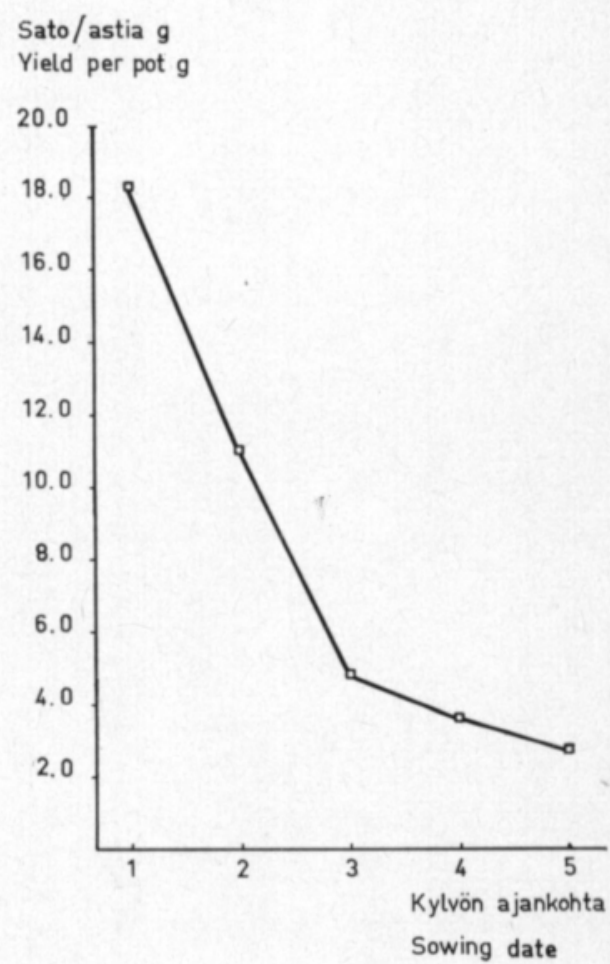


Kilpailu ei vaikuttanut kummankaan kasvilajin juurten osuuteen sadosta. Lehtien osuus muuttui kylvöajankohdan vaikutuksesta ainoastaan sekakasvustossa kasvaneella rypsillä seuraavasti:

\begin{tabular}{|c|c|}
\hline $\begin{array}{l}\text { Rypsin kylvöajankohta } \\
\text { Sowing date of spring turnip rape }\end{array}$ & $\begin{array}{l}\text { Lehtiä } \% \operatorname{sadosta}^{1} \text { ) } \\
\text { Leaf } \%{ }^{1} \text { ) }\end{array}$ \\
\hline $\begin{array}{l}\text { viikkoa ohraa aikaisemmin ......... } \\
1 \text { week before barley }\end{array}$ & $34^{\mathrm{a}}$ \\
\hline $\begin{array}{l}\text { samanaikaisesti kuin ohra .......... } \\
\text { same date as barley }\end{array}$ & $34^{a}$ \\
\hline $\begin{array}{l}\text { viikkoa ohraa myöhemmin ........ } \\
1 \text { week after barley }\end{array}$ & $52^{\mathrm{ab}}$ \\
\hline $\begin{array}{l}2 \text { viikkoa ohraa myöhemmin .... } \\
2 \text { weeks after barley }\end{array}$ & $70^{b}$ \\
\hline $\begin{array}{l}3 \text { viikkoa ohraa myöhemmin .... } \\
3 \text { weeks after barley }\end{array}$ & $77^{b}$ \\
\hline
\end{tabular}

1) Kts. selitystä asetelmassa s. 496.

See explanation p. 496.

Puhtaassa kasvustossa rypsin lehtien osuus sadosta oli keskimäärin $49.0 \%$. Ohran lehtien osuus oli molemmissa kasvustoissa keskimäärin $20.8 \%$.

Jyväsadon osuus ohran kokonaissadosta oli keskimäärin $36.7 \%$. Rypsin kilpailu sekakasvustossa ja kylvöajankohta eivät vaikuttaneet siihen. Sen sijaan rypsin siemensadon osuus jäi pienemmäksi seka- $(2.9 \%)$ kuin puhtaassa kasvustossa $(4.8 \%)$. Kylvöajankohta vaikutti rypsin siemensadon osuuteen puhtaassa, mutta ei sekakasvustossa. Siemensadon osuus oli tällöin suurempi aikaisin kuin myöhään kylvetyssä rypsissä:

Rypsin kylvöajankohta

Sowing date of spring turnip rape
Siemensadon osuus $\% 1$ )

Seed yield \%

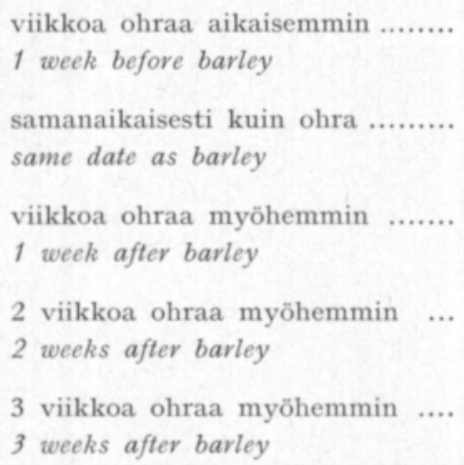

$6.4^{\text {be }}$

$9.8^{\mathrm{e}}$

$5.8^{\mathrm{ab}}$

$0.8^{\mathrm{a}}$

1) Kts. selitystä asetelmassa s. 496.

See explanation p. 496. 
Myös tässä kokeessa ohran valtauskerroin oli kaikissa koejäsenissä korkeampi kuin rypsin (taulukko 4). Rypsin kylvöajankohdan siirtyminen ohran kylvöä myöhäisemmäksi kohotti ohran valtauskerrointa, mutta rypsin valtauskertoimen kehitys oli päinvastainen. Se oli suurimmillaan, kun rypsi kylvettiin ennen ohraa, ja pieneni tämän jälkeen, joskaan ohraa myöhemmin kylvettyjen rypsikasvustojen valtauskerrointen väliset erot eivät olleet tilastollisesti merkitsevät.

Taulukko 4. Kevätrypsin kylvöajankohdan vaikutus sen ja ohran valtauskertoimiin sekakasvustossa. Valtauskertoimen arvo puhtaassa kasvustossa on 1.00 .

Table 4. Effect of the sowing date of spring turnip rape on the crowding coefficients of turnip rape and barley in mixed stand. Crowding coefficient in pure stand is 1.00 .

\begin{tabular}{|c|c|c|}
\hline \multirow[t]{2}{*}{$\begin{array}{l}\text { Kevätrypsin kylvöajankohta } \\
\text { Sowing date of spring turnip rape }\end{array}$} & \multicolumn{2}{|c|}{$\begin{array}{c}\text { Valtauskertoimet }{ }^{\mathbf{1}} \text { ) } \\
\text { Crowding coefficients }^{\mathbf{1}} \text { ) }\end{array}$} \\
\hline & $\begin{array}{l}\text { Ohra } \\
\text { Barley }\end{array}$ & $\begin{array}{l}\text { Kevätrypsi } \\
\text { Spring turnip rape }\end{array}$ \\
\hline 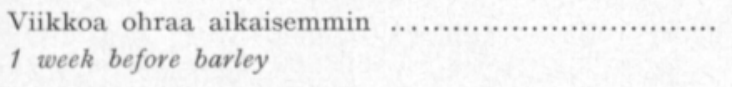 & $1.33^{b}$ & $0.59^{e}$ \\
\hline $\begin{array}{l}\text { Samanaikaisesti kuin ohra } \\
\text { Same date as barley }\end{array}$ & $1.24^{\mathrm{b}}$ & $0.42^{\mathrm{b}}$ \\
\hline $\begin{array}{l}\text { Viikkoa ohraa myöhemmin } \ldots \ldots \ldots \ldots \ldots \ldots \ldots \ldots \ldots \ldots \ldots \ldots \ldots \ldots \ldots \ldots \ldots \\
1 \text { week after barley }\end{array}$ & $1.47^{e}$ & $0.17^{\mathrm{a}}$ \\
\hline $\begin{array}{l}2 \text { viikkoa ohraa myöhemmin } \ldots \ldots \ldots \ldots \ldots \ldots \ldots \ldots \ldots \ldots \ldots \ldots \ldots \ldots \ldots \ldots \\
2 \text { weeks after barley }\end{array}$ & $1.43^{\mathrm{be}}$ & $0.12^{\mathrm{a}}$ \\
\hline 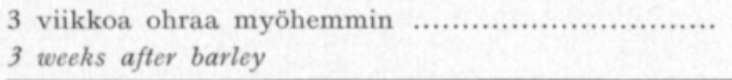 & $1.60^{\mathrm{e}}$ & $0.06^{\mathrm{a}}$ \\
\hline
\end{tabular}

\section{Tulosten tarkastelu}

Ohra ei kummassakaan kokeessa kärsinyt kilpailusta rypsin kanssa, mutta haittasi puolestaan huomattavasti rypsin kasvua. Tämä ilmeni kasvien yksilönpainon, kuiva-ainesadon ja valtauskertoimen kehittymisessä (asetelma s. 496, kuva 1 , taulukot 2 ja 4 ).

Kokeessa I, jossa selvitettiin seossuhteen vaikutusta osapuolien kilpailukykyyn, koitui lajinsisäinen kilpailu ohralle ilmeisesti ankarammaksi kuin kilpailu rypsin kanssa, sillä ohran yksilönpaino jäi pienimmäksi puhtaassa kasvustossa (vrt. s. 00 Bornkamm 1960). Yksilöitten lukuisuuden vuoksi ohran sato kuitenkin oli suurempi puhtaassa kuin sekakasvustossa (taulukko 2).

Kilpailevien kasvien keskinäisen kehitysrytmin ja kehitysnopeuden on todettu vaikuttavan osapuolien kilpailukykyyn (LAURSEN 1971). Aikaisin kasvunsa aloittaneet ja alkukehityksessään nopeat lajit menestyvät kilpailussa paremmin kuin myöhään taimettuvat (STANIforTh 1961). Viikin kokeessa II kevätrypsin kylvöajankohta ohran kylvöön nähden vaikutti selvästi rypsin kilpailukykyyn. Rypsin sato sekakasvustossa oli suurin, kun kylvö suoritettiin ennen ohraa ja väheni kylvön siirtyessä myöhemmäksi (asetelma s. 30). Puhtaassa rypsikasvustossa ei vastaavaa kylvöajan vaikutusta ollut havaittavissa. 
Vaikka ennen ohraa kylvetty rypsi ehti kehittyä 2-lehtiasteelle ohran orastumiseen mennessä (taulukko 1), pystyi ohra vähentämään rypsin satoa sekakasvustossa $\mathbf{7 1 . 5} \%$ puhtaaseen kasvustoon verrattuna. IDRIs ja MILTHORPE (1966) ovat ohran ja rikkasinapin kilpailua tutkiessaan todenneet, että ohra suurempikokoisena kehittyi heti orastumisensa jälkeen dominoivaksi ehkäisten rikkasinapin fotosynteesiä, joka jäi $30-40 \%$ pienemmäksi sekakuin puhtaassa kasvustossa.

Kevätrypsin kilpailuvaikutus ohraan nähden jäi puheena olevassa kokeessa merkityksettömäksi.

\section{Tiivistelmä}

Ohran ja Fenno-kevätrypsin välistä kilpailua selvittävät tutkimukset osoittivat, että ohra voimakkaampana kilpailijana pienensi puhtaaseen kasvustoon verrattuna rypsin yksilönpainoa ja kuiva-ainesatoa sekakasvustoissa, joissa seossuhde ohra-rypsi oli $\mathbf{7 5}-\mathbf{2 5}, 50-50$, ja $25-75 \%$. Ohran yksilönpainoa pienensi tässä kokeessa lajinsisäinen kilpailu, mutta ei kilpailu rypsin kanssa. Suurimman yksilömääränsä ansiosta puhdas ohrakasvusto tuotti kuitenkin runsaamman sadon kuin ohra sekakasvustossa.

Kokeessa II ohra pienensi rypsin yksilönpainoa ja kuiva-ainesatoa sitä enemmän, mitä myöhemmin tämä ohraan verrattuna kylvettiin. Sen sijaan rypsi ei vaikuttanut haitallisesti ohraan.

Myös kasveille laskettu valtauskerroin osoitti ohran kevätrypsiä aggressiivisemmaksi kilpailijaksi molemmissa kokeissa. Ohraan verrattuna myöhäinen rypsin kylvö alensi tämän kilpailukykyä sitä enemmän, mitä myöhemmin kylvö tapahtui.

\section{KIRJALLISUUTTA}

Bornкamm, R. 1961. Zur Lichtkonkurrenz von Ackerunkräutern. Flora 151: 126-143.

ERviö, L-R. 1971. The effect of intra-specific competition on the development of Chenopodium album L. Weed Res. 11: 124-134.

- 1972 a. Growth of weeds in cereal populations. Maatal.tiet. Aikak. 44: 19-28.

_ - 1972 b. Lämpötilan ja poutajakson vaikutus jauhosavikan (Chenopodium album L.) ja viljan väliseen kilpailuun. Maatal.tiet. Aikak. 44: 138-148.

HoFer H. 1970. Über die Zusammenhänge zwischen der Düngung und der Konkurrenzfähigkeit ausgewählter Naturwiesenpflanzen. Diss. 4500:1-70. Zürich.

Idris, H \& MrLthorpe, F. L. 1966. Light and nutrient supplies in the competition between barley and charlock. Oecologia Pl. 1: 143-164.

LAmpeter, W. 1959/60. Gegenseitige Beeinflussung höherer Pflanzen in bezug auf Sprossund Wurzelwachstum, Mineralstoffgehalt und Wasserverbrauch - untersucht an einigen wirtschaftlich wichtigen Futterpflanzen. Wiss. Z. Univ. Leipzig 9:611-722. (Ref. HOFER, H. 1970).

Laursen, F. 1971. Studies of weed competition in barley. K. Veter. Landbohöjsk. Årsskr. 1971: $201-220$.

Staniforth, D. W. 1961. Responses of corn hybrids to yellow foxtail competition. Weeds 9: $132-136$.

VALLE, O. 1951. Kevätrapsi ja kevätrypsi ravintoöljykasveinamme. Kasviöljy 1951: 1-8.

Wir, C. T. de 1960. On competition. Versl. Landbouwk. Onderz. 66: 1-82. 